has written a small handbook on poultry keeping called Winter Eggs; there is a preface by the Principal of the Royal Agricultural Ccllege, Cirencestor, which seyg the book is a thoroughly practical guide. Now, this book contains a great deal about balanced diets, and how to work them out; it would not be right that children should be less wisely fed than chickens.

It will be agreed that it is the province of the housekeeper to see that the meals are suitably composed, skilfully cooked, and invitingly served.

The cost of dietary is not calculated, partly becanse a great deal of the food would come from the garden, which every school should have; even at Dotlieboys Hall there was a garden. The solution of the ventilation problem lies not in cubic feet or electric fans but in open-air life. If goats are not kept, cow's milk will have to be bought; in that case to kill any tubercle bacilli present it shonld be heated to $140^{\circ} \mathrm{F}$. and kept at that temperature for twenty minutes; this will not injure the miik, nor, unfortunately, spore-bearing nicrobes. -I am, etc.,

l.ondon, W.

J. S.

THE CLERGY AS HEALTH MISSIONARIES.

Sir,-I feel that I must take some exception to your statement that the clergy, as a body, do not display much interest in health problems.

In the city of Durham, where there is much slum property, the Dean and Chapter paid a good sum for an inspection of the slum property of the town by an expert. The report he drew up was presented to the corporation, who ignored it for many years.

The late Canon Body worked hard amongst all classes in the city and county of Durham when small-pox was rife. He also threw himself into every movement for the improvement of the conditions of the working classes, and was president of a Citizens' League, which provided a lady health visitor, years before the Durham Corporation would undertake such work. The Archdeacon of Durham has alrrays interested himself in social matters, especially in the need of better houses for the working classes. It is only a few years ago that a very long and comprehensive report on the hausing question was brought before the Durham Diocesan Conference, when Canon Moore Ede tnow Dean of Worcester) was an energetic member of that body.

The late Bishop Tucker of Uganda, when a curate in Durham city, knew much of its slums. Coming back to Durham as a canon, he threw himself into every move. ment for doing some good to the slum property, and was president for a ferv years of the Citizens' League. Canon Cruikshank succeeded Bishop Tucker as president of the league, and he had done much good in securing better dwellings for the working classes in the city of Winchester before coming to Durham. I think that Canon Carnegie can know nothing of the work done in the county of Durham, or he would not have condemned the clergy in the manner stated. - I am, etc.

Ruislip, Oct. 29th.

Edward Jepson, M.D.

SOLDIERS AND VENEREAL DISEASES.

SIR,-During the past two years the Liverpool Medical Institution has distributed over 160,000 copies of pamphlets especially written in plain non-technical language for soldiers, warning them of the dangers and disabilities incurred by contracting these avoidable diseases. The army authorities in Egypt have reprinted the tract for their own use. We desire to enlist your support by the insertion of this letter, and invite inquiries for specimen copies from commanding officers, medical officers, chaplains, social workers, and others interested in our soldiers, addressed to the Librarian, The Medical Institution, fiverpool.-I $\mathrm{am}$, ctc.

November 1st.

Charles J. Macalister President.

THE young farmer who shot Dr. Glyn Jones of Llansawel has been found gnilty of murder but insane.

Dr. Thomas Buxton, of Fazeley, Tamworth, left estate valued at $£ 24,173$. Subject to several life interests, the whole property is left in trust for the building, endowing, and furnishing of a block of buildings to be known as "Buxton's Homes of Rest."

\section{Ohtulurerities and Calleges.}

UNIVERSITY OF CAMBRIDGE. The number of medical students who have entered Cambridge this year is 25, showing a farther falling off fro
entered in 1915, the 64 in 1914, and the 116 in 1913.

Y XIVERSTTY OF WDINBTHGH. Gexeraj, Council.

Sm J. AlrRFy Ewivg, the Vice-Chancellor, presider at the statutory half-yearly meeting of the General Conncil of the University on October 27th. Mr. J. B. Clark conveyed to the Vice-Chaucellor the Council's hearty congratulations on his appointment as Principal, and Sir J. Alfred Ewing, in his reply, took occasion to refer to the University Court, the Senatus, and took occasion to refer to the University Court, the Senatus, and the General Council as the Three Estates of the University
realm, the Council, or Third Estate, being in a sense the most realm, the Council, or Third Estate, being in a se

Among the matters of general interest in the report of the Among the matters of general interest in the report of the
Business Committee was an allusion to the death of the Loril Rector (Lord Kitchener) and to that of the Rev. Canon Hoernlé, M.B., for more than eighteen years a member of the Business Committee; to the Roll of Honour, from which it appeared that over 5,000 men were now serving King and country and 250 had given their lives pro patria ; to the number of matriculatei students $(1,811$ for $1915-16)$, which showed the reduction due to the war; to the admission of women to the medical classes, it being stated that, up to October 16 th, 176 women had matriculated; to the action which had been taken regarding the Preliminary Examination Ordinance; and to the Ordinance for the degree of Bachelor of Education, the University of Edinburgh being the second British university to institute such a degree. There were two other matters of special medical interest. One was the institution of the Lauder Brunton Prize in Pharmacology and Therapentics open to senior students of medicine and to graduates of medicine of not more than five years' standing. The other was the presentation of the report
of the Business Committee anent the foundation of a chair of of the Business Committee anent the foundation of a chair of
tuberculosis in the University, and the draft Ordinance framed tuberculosis in the University, and the draft Ordinance framed
by the University Court in connexion therewith. The Council approved the action of the Business Committec and accepted the report.

It was stated in reply to inquiries that the question of the age limit for principal and professors was still being considered by the Senatus and would be by the Business Committee. Committees were also appointed to consider the question of providing a chspel for the University, and to report on the development of the University after the war in respect of finonce, research, new degrees, training in social service, relation to the allies (exchange of students and professors), etc.

On the recommendation of the Senatus, it was resolved that the suspension of class prizes other than those sleeially the suspension of class prizes other than
endowed should be continued during 1916-17.

\section{UNIVERSITY OF GLASGOW.} General Council.

AT its half-rearly meeting the General Council approved the report of the Joint Commitiee on the ordinance relative to the foundation of a Chair of Ophthalmology, endowed by a sum of $£ 25,000$ bequeathed by Dr. Gavin Paterson Tennent for this purpose. The Vice-Chancellor, Sir. Donald MacAlister, said that the benefaction, which to the Western Infirmary and the university amounted with accumulations to nearly $£ 40,000$, was aniversity amounted with accumulations to nearly $£ 40,000$, was designed by the trustees of the university. for post-graduate teaching, not for under-graduate teaching, it being recognized that to make an ophthalmic surgeon special study was required after the ordinary medical legree had been taken. If the scheme came to fruition Glasgow would have the opportunity
of creating a special school of ophthalmology for practitioner: who proposed to become specialists. To accomplish this it would be necessary to have a head, $\mathrm{a}$ man of high distinction and a laboratory, and also to utilize all facilities for clinical study, not only in the Western Infirmary but in all the infirmaries in Glasgow. It would be necessary also to have teachers of subsidiary subjects, and the fund wonld be able to provicle salaries for them, since the amount it would yield would be double that proposed for the professor's salar'y. In reply to Dr. Leask, he said that

At the same meeting a report from the Business Committee was received, expre-sing general approval of the ordinance for a degree of Bachelor of Education, but suggesting certain modifications.

The same committee reported that the number of graduates and members of the university serving in the militaiy forces of the Crown was 2,806 , of whom 1,359 were graduates; 2,243 were crmmissioned officers, and the honours yained included 13 D.S.O.'s, of which 12 were awarded to members of medica units, and 38 Military Crosses. The losses had unfortunately been heavy - 247 killed, 294 wounded, 12 missing, and 4 prisoner of war. Of the women graduates, no ferver than 684 were regis tered as willing to undertake war work; all save 30 had been emplosed, and the demand continued. 